\title{
THE FOLIC ACID ACTIVITY OF HUMAN LIVERS AS MEASURED WITH LACTOBACILLUS CASEI
}

\author{
MARJORIE K. ROMINE \\ National Institute of Arthritis and Metabolic Diseases, National Institutes of \\ Health, Public Health Service, U.S. Department of Health, Education, \\ and Welfare, Bethesda, Maryland.
}

(Received May 5, 1960)

A generally satisfactory assay procedure for the determination of folic acid activity $(\mathrm{FA})^{1}$ in biological materials is not yet available. The method of Chang (1) for the determination of such activities in livers, based on yield of CF activity, appears to be the best available for this tissue. This procedure requires autolysis of the liver in which the folic acid activity is released as CF. The method is not applicable to specimens which have been sterilized by procedures which inactivate the tissue enzymes. In the preparation of tissues from post-mortem specimens, the manipulations expose the investigator to some hazards, especially that of infection with pathogenic organisms present in these tissues. It seemed desirable to have a method for the preparation of samples for assay in which these potential hazards were reduced.

Baker et al. (2) reported that the FA activity of human serum assayed with $L$. casei provided an adequate index of FA deficiency. Toennies (3) had previously demonstrated the presence of a substance(s) in human blood which was far more active in supplying the FA requirement for $L$. casei than for either $S$. faecalis $R$. or $P$. cerevisiae. The present investigation was stimulated by these observations.

A comparison was made of the FA activity values obtained from human livers after specimens had been prepared for microbiological assay by $(a)$ autolysis (1) and (b) extraction with aqueous potassium ascorbate. It has been found that the FA activity of these extracts prepared by autoclaving in the presence of ascorbate and assayed with $L$. casei is equal to, or greater than, the activity found in autolyzed samples assayed with $S$. faecalis $R$. and $P$. cerevisiae. Such extracts (potassium ascorbate) possess little growth activity for $P$. cerevisiae or $S$. faecalis $R$. Although many questions as to the nature of this activity remain unanswered, it seems advisable to present a preliminary report of these observations since they are likely to have general

\footnotetext{
${ }^{1}$ Key to abbreviations used in this paper: (1) FA, folic acid activity; (2) CF, citrovorum factor or $\mathrm{N}^{5}$-formyl-tetrahydrofolic acid; (3) L. casei, Lactobacillus casei 7469 ; (4) P. cerevisiae, Pediococcus cerevisiae or Leuconostoc citrovorum 8081 ; (5) S. faecalis R., Streptocnccus faecalis $R$.
} 
application to the problem of FA assays in biological materials.

\section{EXPERIMENTAL}

\section{Materials and Methods}

The microbiological procedures described previously $(4,5)$ for the determination of FA and CF were employed using the test organisms, $S$. faecalis $R$. and $P$. cerevisiae. The FA assay with $L$. casei, employing the medium of Teply and Elvehjem (6) was modified by replacing the acid hydrolyzed casein in the medium with a combination of acid and enzymatically hydrolyzed casein. Calcium leucovorin was employed as a microbiological reference standard and was corrected for the inactive isomer.

METHOD A: Autolyzed Liver Preparation - A portion of the frozen liver was prepared for analysis using Chang's autolytic procedure (1). The latter was modified by homogenizing the sample in a Virtis homogenizer with buffer $^{2}$, using $5 \mathrm{ml}$ buffer per $\mathrm{g}$ of liver. After the recommended incubation time and inactivation, the liver-buffer solution was diluted with water to a volume of $25 \mathrm{ml}$ per $\mathrm{g}$ liver and filtered. The filtrate was diluted to assay range with water, added to the basal media, autoclaved, and assayed for $\mathrm{CF}$ (P. cerevisiae) and FA (L. casei and S. faecalis R.).

METHOD B: Ascorbate Treated Preparation-A sample of frozen liver was suspended in aqueous potassium ascorbate solution $(6 \mathrm{mg}$ per $\mathrm{ml}, \mathrm{pH} 6.0$, $1 \mathrm{~g}$ liver in $10 \mathrm{ml}$ solution) by homogenization in a Viritis. The ascorbateliver extract was autoclaved 30 minutes at $15 \mathrm{psi}$ and cooled. The volume was adjusted to $30 \mathrm{ml}$ per $\mathrm{g}$ of liver with potassium ascorbate solution, the suspension centrifuged, and the clear supernatant poured off for assay. The supernatant was diluted to assay range with ascorbate (See above) and added aseptically to autoclaved sterile medium (5). Potassium ascorbate was added aseptically to each assay tube so that the total content was brought to $6 \mathrm{mg}$ per $10 \mathrm{ml}$ and assayed for CF (P. cerevisiae) and FA (L. casei).

The samples of human livers used in this study were quick-frozen immediately after section and stored at $-10^{\circ}$ until they were prepared for assay. An aliquot of liver was weighed, homogenized and prepared by each of the above described methods. These extracts were assayed in duplicate. The procedures were repeated on the same tissue after an interval of 1 to 60 days. The values shown in Table I represent the averages of a minimum of four assays.

\section{RESULTS}

In Table I are shown the results of the assay of a number of samples of human livers obtained at autopsy. The CF activity ( $P$. cerevisiae values) and FA activity ( $S$. faecalis $R$. and $L$. casei values) are shown for liver autolyzed

\footnotetext{
${ }^{2} 10 \mathrm{ml} M$ buffer $\left(\mathrm{KH}_{2} \mathrm{PO}_{4}-\mathrm{K}_{2} \mathrm{HPO}_{4}, \mathrm{pH} 8.0\right)$ plus $10 \mathrm{ml}$ aqueous potassium ascorbate (100 $\mathrm{mg}$ per $\mathrm{ml}, \mathrm{pH} 6.0$ ), and diluted with water to $100 \mathrm{ml}$.
} 
Table I

Folic Acid Activity in Human Liver Samples

\begin{tabular}{|c|c|c|c|c|c|c|}
\hline I & II & III & IV & $\mathrm{V}$ & VI & VII \\
\hline \multirow{2}{*}{$\begin{array}{l}\text { Liver } \\
\text { sample }\end{array}$} & \multicolumn{3}{|c|}{ Method A - autolysate ${ }^{a}$} & \multicolumn{2}{|c|}{ Method B-ascorbate extract ${ }^{b}$} & $(\mathrm{~V}-\mathrm{III}) \times 100$ \\
\hline & L. casei & P. cerevisiae & S. faecalis $R$. & L. casei & P. cerevisiae & III \\
\hline & $\mu g / g$ & $\mu g / g$ & $\mu g / g$ & $\mu g / g$ & $\mu g / g$ & \\
\hline $\mathrm{H}-1$ & 5.38 & 4.35 & 3.90 & 7.83 & - & 80.0 \\
\hline $\mathrm{H}-2$ & 3.97 & 3.30 & 2.52 & 5.35 & - & 62.1 \\
\hline $\mathrm{H}-3$ & 6.04 & 3.17 & 3.04 & 4.20 & - & 32.4 \\
\hline $\mathrm{H}-4$ & 6.36 & 4.72 & 4.57 & 4.78 & - & 1.3 \\
\hline $\mathrm{H}-5$ & 4.78 & 2.48 & 2.49 & 2.84 & 0.36 & 14.5 \\
\hline $\mathrm{H}-6$ & 4.46 & 3.31 & 3.25 & 4.29 & 0.98 & 29.6 \\
\hline $\mathrm{H}-7$ & 4.69 & 3.94 & - & 4.65 & - & 18.0 \\
\hline $\mathrm{H}-8$ & 4.30 & 2.51 & - & 7.64 & - & 204.4 \\
\hline $\mathrm{H}-9$ & 3.64 & 2.64 & 2.48 & 5.16 & 0.89 & 95.4 \\
\hline $\mathrm{H}-10$ & 4.31 & 3.14 & - & 3.94 & - & 25.5 \\
\hline $\mathrm{H}-11$ & 12.11 & 8.46 & 8.50 & 10.80 & - & 27.6 \\
\hline $\mathrm{H}-12$ & 8.60 & 7.18 & - & 6.80 & - & -5.3 \\
\hline $\mathrm{H}-13$ & 5.88 & 4.70 & 4.91 & 5.74 & 0.38 & 22.1 \\
\hline $\mathrm{H}-14$ & 6.71 & 4.72 & - & 7.89 & - & 67.2 \\
\hline $\mathrm{H}$-average & 5.80 & 4.19 & 3.96 & 5.85 & 0.65 & 48.2 \\
\hline$C-1$ & 3.30 & 2.04 & 2.21 & 3.69 & 0.65 & 80.9 \\
\hline$C-2$ & inhib. & 3.99 & 4.02 & inhib. & - & - \\
\hline$C-3$ & 7.11 & 5.38 & 5.38 & 3.90 & - & -27.5 \\
\hline$C-4$ & 3.34 & 3.13 & - & 3.79 & 一 & 21.1 \\
\hline$C-5$ & 3.06 & - & - & 3.02 & 一 & - \\
\hline $\mathrm{C}-6$ & 4.57 & 4.15 & - & 4.33 & - & 4.3 \\
\hline $\mathrm{C}-7$ & 1.89 & 1.08 & 1.06 & 1.96 & - & 81.5 \\
\hline$C-8$ & 3.32 & 2.83 & 2.80 & 2.40 & - & -15.2 \\
\hline $\mathrm{C}-9$ & 5.79 & 4.46 & 4.22 & 4.92 & - & 10.3 \\
\hline$C-10$ & 1.41 & 0.72 & 0.81 & 1.66 & 0.74 & 130.6 \\
\hline$C-11$ & 4.70 & 3.32 & - & 5.67 & - & 70.8 \\
\hline$C-12$ & 2.03 & 1.56 & - & 2.59 & 一 & 66.0 \\
\hline$C-13$ & 5.05 & 4.44 & 一 & 4.98 & - & 12.2 \\
\hline $\mathrm{C}-14$ & 0.63 & 0.55 & - & 1.60 & - & 190.9 \\
\hline $\mathrm{C}$-average & 3.55 & 2.90 & 2.93 & 3.42 & 0.70 & 52.5 \\
\hline $\mathrm{L}-1$ & 1.24 & 0.64 & 0.62 & - & - & - \\
\hline $\mathrm{L}-2$ & 1.84 & 0.93 & 0.93 & 0.60 & - & -35.5 \\
\hline $\mathrm{L}-3$ & 1.83 & 1.15 & 0.87 & 1.86 & - & 61.7 \\
\hline $\mathrm{L}-4$ & inhib. & 0.18 & 0.17 & inhib. & - & - \\
\hline $\mathrm{L}-5$ & inhib. & 0.18 & - & inhib. & - & - \\
\hline $\mathrm{L}-6$ & 0.67 & 0.40 & - & 0.85 & - & 112.5 \\
\hline $\mathrm{L}-7$ & inhib. & 0.52 & - & inhib. & $\ldots$ & $\ldots$ \\
\hline $\mathrm{L}-8$ & 2.04 & 1.77 & - & 3.04 & - & 71.8 \\
\hline $\mathrm{L}-9$ & 1.66 & 1.48 & - & 2.94 & - & 98.7 \\
\hline $\mathrm{L}-10$ & 3.78 & 2.84 & - & 7.11 & - & 150.4 \\
\hline $\mathrm{L}-11$ & 1.50 & 1.30 & - & 2.11 & - & 62.3 \\
\hline $\mathrm{L}-12$ & 3.96 & 3.54 & - & 6.10 & - & 72.3 \\
\hline $\mathrm{L}-13$ & inhib. & 0.91 & - & 1.38 & - & 51.6 \\
\hline $\mathrm{L}-14$ & 1.03 & 0.68 & 0.68 & 0.86 & 一 & 26.5 \\
\hline L-average & 1.96 & 1.18 & 0.65 & 2.68 & - & 67.2 \\
\hline
\end{tabular}

a Method A-autolyzed extracts, assayed by usual procedure.

$b$ Method B-ascorbate extracts, assayed aseptically.

$\mathrm{H}$, congenital heart disease, rheumatic heart disease, etc.

$\mathrm{C}$, carcinoma of the cervix, breast, lungs, etc.

$\mathrm{L}$, myelogenous and lymphocytic leukemia.

Inhib., inhibitory. 
by the procedure of Chang (1); the FA activities ( $L$. casei) and a limited number of $C F$ values ( $P$. cerevisiae) are shown for the potassium ascorbate extracted livers.

In the autolyzed samples the ratio of $\mathrm{CF}$ ( $P$. cerevisiae) to FA activity $(S$. faccalis $R$.) is essentially one. These results are in agreement with the observations of Chang who analyzed liver autolysates of several animal livers and found that under these conditions the FA activity is released as CF. It may further be noted from Table I that the FA values obtained with $L$. case on the autolysates (Method A), in general, vary from values equivalent to the $\mathrm{CF}$ content to values twice as high.

The $P$. cerevisiae $(\mathrm{CF})$ activities of potassium ascorbate extracted tissues in Table I are much lower than those of autolyzed tissues. Similarly, S. faecalis $R$. (FA) gave low values with these extracts. However, it may be seen that the same extracts when assayed with $L$. casei (Method B) show, with few exceptions, values equal to or greater than the $\mathrm{CF}$ content of the autolyzed samples. For the group of samples obtained from heart patients, the average $L$. casei values for the ascorbate extract was $5.83 \mu \mathrm{g}$ per g, and the corresponding value for the autolysate was $4.19 \mu \mathrm{g}$ per $\mathrm{g}$.

The assay organism, L. casei, seems to be far more sensitive to the pre-

TABLE II

Effect of Storage on Activity of Ascorbate Extracts

\begin{tabular}{ccc}
\hline & \multicolumn{3}{c}{ No. of days at $-10^{\circ}$} \\
\cline { 2 - 3 } Liver sample & 0 & 28 \\
& $m \mu g / m l$ & $m \mu g / m l$ \\
C -13 & 160 & 168 \\
$\mathrm{C}-6$ & 125 & 130 \\
$\mathrm{U}-1$ & 96 & 93 \\
$\mathrm{H}-10$ & 112 & 100
\end{tabular}

Values were obtained with $L$. case $i$ in the aseptic assay.

TABLE III

Reproducibility of Folic Acid Values Using Method A and Method B

\begin{tabular}{|c|c|c|c|c|c|c|}
\hline \multirow{2}{*}{$\begin{array}{l}\text { Liver } \\
\text { sample }\end{array}$} & \multirow{2}{*}{ Organism } & \multirow{2}{*}{ Method } & \multirow{2}{*}{$\begin{array}{l}\text { Date of } \\
\text { extraction }\end{array}$} & \multicolumn{3}{|c|}{ Assay of extract $(m \mu g / m l)$} \\
\hline & & & & Day 1 & Day 2 & Day 3 \\
\hline $\mathrm{H}-8$ & $\begin{array}{l}\text { P. cerevisiae } \\
P . \text { cerevisiae } \\
\text { L. casei } \\
\text { L. casei }\end{array}$ & $\begin{array}{l}\mathrm{A} \\
\mathrm{A} \\
\mathrm{B} \\
\mathrm{B}\end{array}$ & $\begin{array}{l}11 / 3 \\
11 / 9 \\
10 / 15 \\
10 / 19\end{array}$ & $\begin{array}{r}84.0 \\
96.0 \\
264.0 \\
216.0\end{array}$ & $\begin{array}{l}110.0 \\
110.0 \\
288.0 \\
256.0\end{array}$ & \\
\hline $\mathrm{C}-8$ & $\begin{array}{l}\text { P. cerevisiae } \\
P . \text { cerevisiae } \\
\text { L. casei } \\
\text { L. casei }\end{array}$ & $\begin{array}{l}\mathrm{A} \\
\mathrm{A} \\
\mathrm{B} \\
\mathrm{B}\end{array}$ & $\begin{array}{c}12 / 3 \\
1 / 6 \\
12 / 8 \\
12 / 16\end{array}$ & $\begin{array}{l}22.0 \\
22.4 \\
41.0 \\
52.0\end{array}$ & $\begin{array}{l}23.2 \\
19.8 \\
56.0 \\
62.0\end{array}$ & 58.0 \\
\hline $\mathrm{L}-8$ & $\begin{array}{l}P . \text { cerevisiae } \\
P . \text { cerevisiae } \\
\text { L. casei } \\
\text { L. casei }\end{array}$ & $\begin{array}{l}\mathrm{A} \\
\mathrm{A} \\
\mathrm{B} \\
\mathrm{B}\end{array}$ & $\begin{array}{l}9 / 17 \\
9 / 22 \\
9 / 21 \\
9 / 23\end{array}$ & $\begin{array}{r}74.0 \\
69.0 \\
98.0 \\
116.0\end{array}$ & $\begin{array}{r}64.0 \\
76.0 \\
100.0 \\
92.0\end{array}$ & \\
\hline
\end{tabular}


sence of inhibitory substances in the samples (presumably residual drugs employed in treatment) than is $S$. faecalis $R$. or $P$. cerevisiae.

The effect of storage at $-10^{\circ}$ on the activity of potassium ascorbate extracts of liver was examined. The results shown in Table II indicate the extracts may be stored in the frozen state for a period of one month without suffering any loss of activity for $L$. casei. The extraction methods employed for measuring the FA activity of human liver give relatively reproducible results (Table III).

\section{DISCUSSION}

Although the nature of the substance measured by $L$. casei in the potassium ascorbate extracts is unknown, it is presumed to be a derivative of FA. In general, values obtained with this organism in the above extracts were as high as with autolysates. Thus, it appears that this organism permits an assay for the FA in tissues which have not been autolyzed or subjected to enzymatic digestion. It appears that additional work would be fully justified in attempting to develop and validate a general assay procedure for various biological materials employing ascorbate extracts and $L$. casei as assay organism.

With respect to its microbiological growth activity, the substance(s) in human liver liberated after autoclaving with potassium ascorbate and responding in the aseptic assay appears to be closely related to the material in blood responsible for $L$. casei activity (7).

Girdwood (8) has analyzed the livers of three non-anemic human subjects for FA activity. The livers were prepared for analysis by autolysis in the presence and absence of pancreatin and assayed with $S$. faecalis $R$. and $P$. cerevisiae. He found values in the region of $1.7 \mu \mathrm{g}$ per $\mathrm{g}$ for one sample and $5.0 \mu \mathrm{g}$ per $\mathrm{g}$ for the other two samples. In the present study, most of the values found for livers of heart and carcinoma diseased patients in which $P$. cerevisiae and $S$. faecalis $R$. were used, fall into this range. In general, the post-mortem specimens from subjects with leukemia have significantly less FA activity than specimens from heart or carcinoma patients. These lowered activities may be a reflection of the disease per se or a consequence of the chemotherapy with anti-folic acid compounds which most of these patients have received.

\section{SUMMARY}

It has been demonstrated that extracts of human livers prepared with potassium ascorbate contain a derivative which is very active in supplying the FA requirement for $L$. casei, but only slightly so for $P$. cerevisiae or $S$. faecalis $R$. No autolytic or enzymatic treatment is required for the release of this activity. 


\section{ACKNOWLEDGMENT}

The author is indebted to Dr. Milton Silverman for many pertinent suggestions and to Dr. John C. Keresztesy for his advice and encouragement during the course of this investigation.

The author wishes to thank Mr. John T. Romine for obtaining post-mortem specimens and for his interest and cooperation in this project.

\section{REFERENCES}

1. Chang, S.C., J. Biol. Chem. 200, 827 (1953).

2. Baker, H., Herbert, V., Frank, O., Pasher, I., Hutner, S.H., Wasserman, L. R., and Sobotka, H., Clin. Chem. 5, 275 (1959).

3. Toennies, G., Frank, H. G., and Gallant, D. L., J. Biol. Chem. 200, 23 (1953).

4. Keresztesy, J.C., and Silverman, M., ibid. 183, 473 (1950).

5. Silverman, M., Keresztesy, J.C., Kova1, G. J., and Gardiner, R. C., ibid. 226, 83 (1957).

6. Teply, L. J., and Elvehjem, C. A., ibid. 157, 303 (1945).

7. Toennies, G., Usdin, and Phillips, P. M., ibid. 221, 855 (1956).

8. Girdwood, R.H., Biochem. J. 52, 28 (1952). 